\title{
Selection of Cocoa Tree (Theobroma cacao Linn) Endophytic Bacteria Solubilizing Tri-Calcium Phosphate, Isolated from Seedlings Grown on Soils of Six Producing Regions of Côte d'Ivoire
}

\author{
Adama Ouattara ${ }^{1}$, Klotioloma Coulibaly², Ibrahim Konate ${ }^{1 *}$, Boubacar Ismaël Kebe ${ }^{2}$, \\ Abiba Sanogo Tidou ${ }^{1}$, Abdelkarim Filali-Maltouf ${ }^{3}$
}

\begin{abstract}
${ }^{1}$ UFR Agro-Forestry and Environment, Department of Biochemistry and Microbiology, Laboratory of Agrovalorization, Jean Lorougnon Guede University, Daloa, Côte d'Ivoire

${ }^{2}$ National Center for Agronomic Research (CNRA), Laboratory of Phytopathology, Divo, Côte d'Ivoire

${ }^{3}$ Faculty of Sciences, Laboratory of Microbiology and Molecular Biology, University Mohammed V-Agdal, Rabat, Morocco

Email: coolkotiolo@yahoo.fr, `konatibrahim@yahoo.fr, filalimaltouf@gmail.com
\end{abstract}

\begin{abstract}
How to cite this paper: Ouattara, A., Coulibaly, K., Konate, I., Kebe, B.I., Tidou, A.S. and Filali-Maltouf, A. (2019) Selection of Cocoa Tree (Theobroma cacao Linn) Endophytic Bacteria Solubilizing Tri-Calcium Phosphate, Isolated from Seedlings Grown on Soils of Six Producing Regions of Côte d'Ivoire. Advances in Microbiology, 9, 842852.
\end{abstract}

https://doi.org/10.4236/aim.2019.99051

Received: July 22, 2019

Accepted: September 15, 2019

Published: September 18, 2019

Copyright (๑) 2019 by author(s) and Scientific Research Publishing Inc. This work is licensed under the Creative Commons Attribution International License (CC BY 4.0).

http://creativecommons.org/licenses/by/4.0/

\section{c. (i) Open Access}

\begin{abstract}
Phosphorus (P) is an essential macronutrient for the growth and development of cocoa tree (Theobroma cacao Linn). Most of the soils used for cocoa farming in Côte d'Ivoire are low in phosphorus. But cocoa farmers generally have a widespread reluctance to invest in chemicals fertilizers due to high costs and environmental associated risk. Phosphate Solubilizing Bacteria (PSB) are kwon to play an important role in supply of phosphorous to plants in a sustainable manner in $\mathrm{P}$ deficient soils. The aim of this research was to screen the endophytic bacteria of cocoa nurseries able to solubilize tri-calcium phosphate. Seedlings of two varieties of cocoa (P7 and NA32) and seedlings of an all-comer, were grown on eighteen (18) samples soils collected in six producing regions of Côte d'Ivoire. A total of 218 endophytic bacteria were isolated and tested on the Pikovskaya's agar medium, containing $\mathrm{Ca}_{3}\left(\mathrm{PO}_{4}\right)_{2}$. The colonies with clear zone around the microbial growth were suspected as phosphate solubilizing bacteria. Out of 218 bacteria, 90 (41.28\%) showed a clear zone around colonies after 7 days of incubation. The Phosphate Solubilization Index (PSI) ranged from $20 \%$ to $200 \%$. Bacterial isolated from the soils of Duékoué locality showed the highest mean index of $137.67 \%$. Five PSB (CEBSP5, CEBSP6, CEBSP7, CEBSP8, and CEBSP9) from Duékoué soils and two PSB (CEBSP12 and CEBSP13) from Soubré soils have a PSI ranged from $150 \%$ to $200 \%$. Further study in greenhouse and in field condition will confirm the use of these PSB as biofertilizer to increase the available P content in soils, reduce environmental pollution and promote sustainable agriculture.
\end{abstract}




\section{Keywords}

Endophytic Bacteria, Theobroma cacao, Ti-Calcium Phosphate, Solubilization, Biofertilizer

\section{Introduction}

Phosphorus is one of the major nutrients for plant growth, and involved in the early stages of plant development [1]. It plays a key role in roots growth, tissue rigidity, formation of inflorescences and fruits [2]. It is also essential in the synthesis of living plant matter, in resistance to cold and diseases [3]. Despite its content is relatively high in soil, not all phosphorus is present in an available form for the roots [4]. Otherwise, plants are only able to assimilate phosphorus in its soluble forms primary and secondary orthophosphate ions $\mathrm{H}_{2} \mathrm{PO}_{4}^{-}$and $\mathrm{HPO}_{4}^{2-}$ [5]. Then, to avoid deficiencies, phosphate fertilizer inputs may be recommended. But added $75 \%$ to $95 \%$ of phosphate fertilizer is precipitated by metals complexes existing in the soils [6]. In addition, these chemical fertilizers have a negative impact on the environment.

Phosphate Solubilizing Microorganisms (PSM) play an important role in plant nutrition and growth, especially when phosphate fertilizers are used extensively for long periods of time. It has been proven that agricultural application of PSM boosts crop yields [7] [8]. The use of efficient phosphate-solubilizing microorganisms, opens a new horizon for better crop productivity and for greater yield performance without affecting the soil health. Phosphate solubilizing microorganism plays an important role in the plant nutrition through increase in $\mathrm{P}$ uptake by the plants and their use as PGPR (Plant Growth Promoting Rhizobacteria) is an important contribution to biofertilization of agricultural crops [9] [10]. This could reduce production costs, minimize the misuse of chemical fertilizers, and increase soil fertility and crop yields over the long term [11]. In view of this property, these microorganisms are an ecological and economic interest for a sustainable agriculture. Recently, phosphate solubilizing bacteria (PSB) have attracted the attention of agriculturists for their use as biofertilizers to improve plant growth and yield [12].

In Côte d'Ivoire, $81 \%$ of the soils in the forest zone where cocoa (Theobroma cacao Linn) cultivation is practiced are low in phosphorus [13]. In addition, the cost of chemical fertilizers remains high for most farmers who are forced to resort to organic fertilizers such as poultry manure and sometimes cocoa pod compost. But this can pose a risk of plant infections with fungal agents such as Phytophthora, which causes brown pod rot [14]. Thus, it is necessary to investigate other sustainable and less expensive ecological alternatives to the chemical fertilization of cocoa. There is no data on the cocoa tree endophytic bacteria solubilizing the insoluble forms of soil phosphates into available forms for plants.

The aim of this research was to screen the endophytic bacteria of cocoa nurse- 
ries able to solubilize tri-calcium phosphate. Specifically, this study investigated the ability of these cocoa isolates to form a transparent halo on solid Pikovkaya (PVK) medium and compare the efficiency of these isolates according to the provenances of soils collected in six producing regions of Côte d'Ivoire, on which the nurseries were carried out.

\section{Materials and Methods}

\subsection{Materials}

\subsubsection{Soils Samples}

Eighteen (18) soils samples under cocoa (Theobroma cacao Linn) farms were collected in six producing regions of Ivory Coast whose central's localities are Aboisso, Abengourou, Daloa, Divo, Duékoué and Soubré. In each region, three soil samples were taken from three different plantations located at least within 15 kilometers of the central locality (Figure 1).

\subsubsection{Plants Samples}

The plant material was consisted of young cocoa seedlings (Theobroma cacao Linn) from a 45 day after sowing cocoa nursery, of two varieties (P7 and NA32) and an all-comer (Tv) grown on the collected soils. The seeds of the two varieties P7 and NA32 were collected at the National Research Center for Agronomic (CNRA) station of Divo (Côte d'Ivoire), the all-comer cocoa seeds were come from pods taken in orchards in the locality of Daloa. The nursery was made in

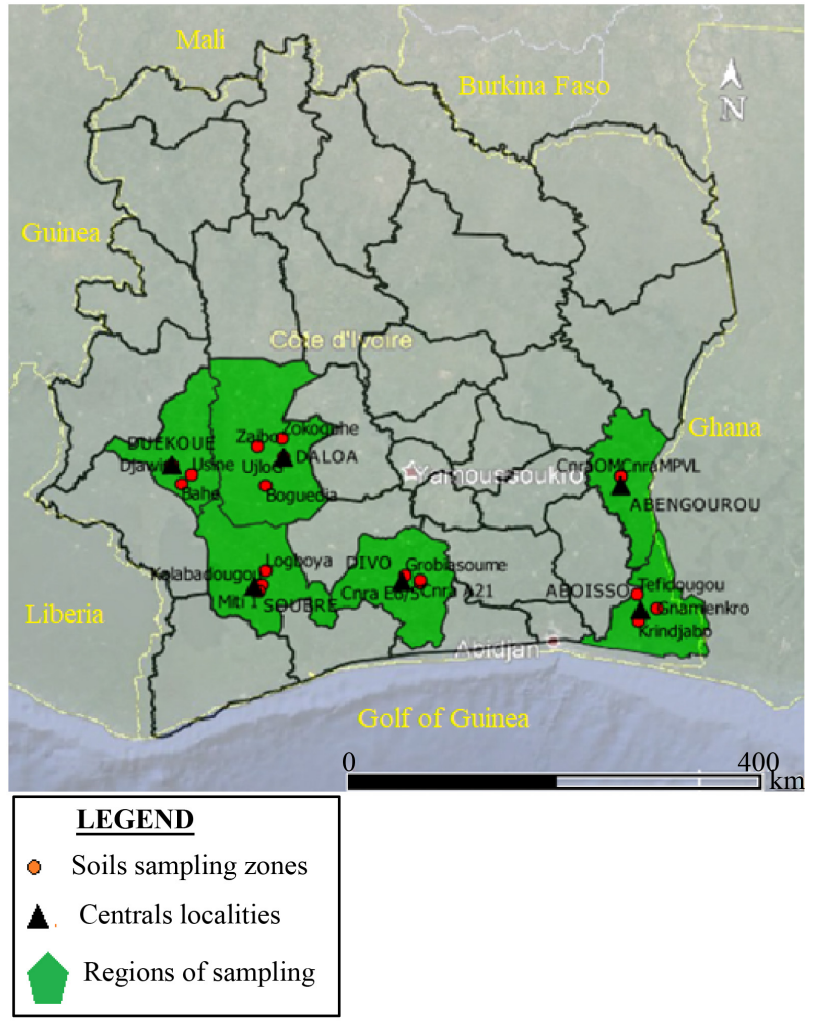

Figure 1. Map of soils sampling zones in Côte d'Ivoire. 
order to trap rhizobacteria from collected soils. The varieties NA32 and P7 are respectively known to be susceptible and resistant to cocoa black pod in the field.

\subsubsection{Bacteria Strains}

A total of two hundred and eighteen (218) endophytic bacteria were isolated from the organs (roots, stems, leaves) of cocoa seedlings were tested in vitro to solubilize tri-calcium phosphate. The isolates considered as efficient were coded “CEBSP” (Cocoa Endophytic Bacteria Solubilizing Phosphate Tri-Calcium).

\subsection{Methods}

\subsubsection{Soils Sampling}

Soil samples were removed aseptically in the upper layers about $0-20 \mathrm{~cm}$ deep under cocoa trees. Before any sampling, the dead leaves of cocoa are released. Each sample $(10 \mathrm{~kg}$ ) of soil is obtained by mixing five samples of $2 \mathrm{~kg}$ of soil, taken at the four ends and at the center of a plot of at least one hectare of cocoa in production, after each sampling of materials are disinfected with alcohol.

\subsubsection{Phosphate Solubilizing Test}

The test was carried out on the solid PVK medium [15]. Before the test all bacteria were grown in a Yeast Extract Mannitol (YEM) broth during 48 hours to obtain bacterial suspensions of $10^{9}$ cells $/ \mathrm{ml}$. A volume of $5 \mu \mathrm{l}$ of bacterial suspension of each isolate, was deposited in duplicate on the surface of the solid PVK medium. This medium is composing by of g/l: Glucose (10), Yeast extract (0.5), tri-calcium phosphate (5); ammonium sulfate (0.5); sodium chloride (0.2); magnesium sulfate $(0.1)$; potassium chloride $(0.2)$; manganese sulfate $(0.002)$; iron sulfate (0.002) and agar (15), $\mathrm{pH}$ is adjusted to 7.0 [15]. After incubation at $28^{\circ} \mathrm{C}$ $\pm 2^{\circ} \mathrm{C}$ for 7 days, the isolates capable of solubilizing the tri-calcium phosphate are surrounded by a transparent halo colony. The solubilization index of each efficient isolate was obtained by measuring the diameter of the colony and the diameter of the surrounding halo (Figure 2). The phosphate solubilization indices (PSI) were calculated according to the following formula [16]:

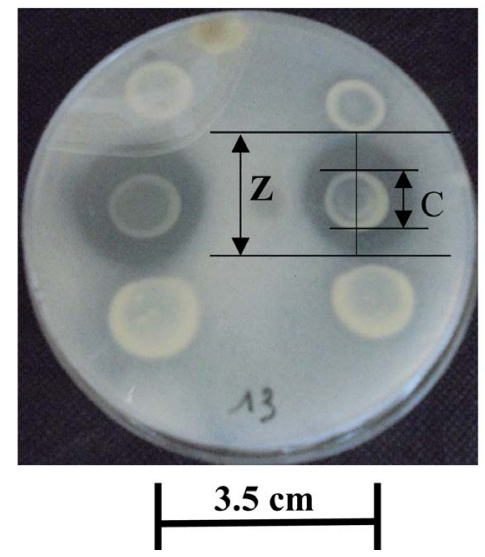

Figure 2. Phosphate solubilization on solid PVK medium. $C=$ Bacteria colony diameter $(\mathrm{mm})$ and $Z=$ Phosphate solubilization zone or halo diameter $(\mathrm{mm})$. 


$$
\text { PSI }=((Z-C) / C) \times 100
$$

PSI $=$ Phosphate solubilization index.

$Z=$ Diameter of the clear zone or halo $(\mathrm{mm})$.

$C=$ Diameter of the colony $(\mathrm{mm})$.

\section{Statistical Analysis}

All data obtained were analyzed using $\mathrm{R}$ version 3.5.1 software [17]. All data reported were means of at least three replicates. One-way analysis of variance and Student-Newman-Keuls test were used to compare phosphate solubilization index of bacteria isolated from cocoa plants grown on different soils. Differences with $\mathrm{P}<0.05$ were considered significant. For organs and varieties types, data do not follow the normal distribution, the non-parametric test of Mood was used to compare the medians of the tri-calcium phosphate solubilization indices.

\section{Results and Discussion}

\subsection{Results}

\subsubsection{Endophytic Bacteria of Cocoa Solubilizing Phosphate}

Bacteria solubilizing tri-calcium phosphate $\mathrm{Ca}_{3}\left(\mathrm{PO}_{4}\right)_{2}$ were characterized by the appearance of a clear zone around colonies on solid PVK medium after 7 days of incubation at $28^{\circ} \mathrm{C} \pm 2{ }^{\circ} \mathrm{C}$ (Figure 2). A total of 90 bacteria among $218 \%$ or $41.28 \%$ of the collection were able to solubilize the tri-calcium phosphate on solid PVK medium. The solubilization indices were ranged from $20 \%$ to $200 \%$. Twenty-two isolates have a solubilization index greater than or equal to $100 \%$. Five isolates (CEBSP5, CEBSP6, CEBSP7, CEBSP8, and CEBSP9) from cocoa plants grown on Duékoué soils and two isolates (CEBSP12 and CEBSP13) from Soubré soils have a solubilization index ranged from $150 \%$ to $200 \%$ (Table 1).

Table 1. List of cocoa endophytic bacteria having phosphate solubilizing index $\geq 100 \%$.

\begin{tabular}{lcccc}
\hline Strains & Soils origins & Varieties & Organs & PSI (\%) \\
\hline$C E B S P 1$ & Aboisso & $\mathrm{P} 7$ & Root & 100 \\
$C E B S P 2$ & Aboisso & $\mathrm{P} 7$ & Root & 100 \\
$C E B S P 3$ & Duékoué & $\mathrm{P} 7$ & Root & 114 \\
$C E B S P 4$ & Duékoué & $\mathrm{P} 7$ & Root & 129 \\
$C E B S P 5$ & Duékoué & $\mathrm{P} 7$ & Root & 150 \\
$C E B S P 6$ & Duékoué & $\mathrm{P} 7$ & Root & 150 \\
$C E B S P 7$ & Duékoué & $\mathrm{P} 7$ & Root & 186 \\
$C E B S P 8$ & Duékoué & $\mathrm{P} 7$ & Root & 200 \\
$C E B S P 9$ & Duékoué & NA32 & Stem & 191 \\
$C E B S P 10$ & Soubré & $\mathrm{P} 7$ & Leave & 114 \\
$C E B S P 11$ & Soubré & $\mathrm{P} 7$ & Leave & 143 \\
$C E B S P 12$ & Soubré & $\mathrm{P} 7$ & Stem & 160 \\
\hline
\end{tabular}




\begin{tabular}{cccll} 
Continued & & & & \\
\hline$C E B S P 13$ & Soubré & $\mathrm{P7}$ & Leave & 150 \\
$C E B S P 14$ & Daloa & $\mathrm{Tv}$ & Leave & 122 \\
$C E B S P 15$ & Daloa & $\mathrm{Tv}$ & Leave & 111 \\
$C E B S P 16$ & Daloa & $\mathrm{Tv}$ & Root & 125 \\
$C E B S P 17$ & Daloa & $\mathrm{Tv}$ & Root & 100 \\
$C E B S P 18$ & Daloa & $\mathrm{Tv}$ & Root & 143 \\
$C E B S P 19$ & Daloa & $\mathrm{Tv}$ & Root & 133 \\
$C E B S P 20$ & Daloa & $\mathrm{Tv}$ & Root & 125 \\
$C E B S P 21$ & Daloa & $\mathrm{Tv}$ & Stem & 133 \\
$C E B S P 22$ & Daloa & $\mathrm{Tv}$ & Root & 100
\end{tabular}

\subsubsection{Comparison of the Means Indices of Tri-Calcium Phosphate Solubilization}

In general, the means solubilization indices of tri-calcium phosphate of cocoa (Theobroma cacao Linn) endophytic bacteria were significantly different ( $\mathrm{p}<$ 0.001 ) depending on the localities from which the soil originate. Those prove that soil composition significantly influences the ability of bacteria to solubilize phosphate.

A difference was observed between the means of the phosphate solubilization indices of cocoa endophytic bacteria from different soils of the six regions (Figure 3). Bacteria isolated from cocoa plants grown on Duékoué soils were the most efficient and have the highest phosphate solubilization index ranged from $100 \%$ to $200 \%$ with an average index of $137.67 \%$ followed by those from Soubré and Aboisso soils. The lows solubilization indices were observed with the bacteria from Divo and Abengourou soils.

Student-Newman-Keuls test showed a significant difference $(\mathrm{p}<0.001)$ between the means indices of bacteria isolated from Duékoué soils and those of Soubré, Aboisso, Daloa Abengourou, and Divo. According to this test the means with the same letter are not significantly different (Figure 3).

There was no significant difference $(p=0.0985)$ between the medians of phosphate solubilization indices of bacteria populations from different varieties P7, NA32 and all-comers (Figure 4(a)) on the one hand and those from different organs of cocoa plants $(\mathrm{p}=0.4685)$ leaves, stems, and roots on the other hand (Figure 4(b)).

\subsection{Discussion}

The results obtained in vitro showed that 90 isolates in our collection showed a clear zone around the colonies on the solid PVK medium and the diameter of this zone varied from one isolate to another. This proved that these cocoa (Theobroma cacao Linn) endophytic bacteria are capable of producing enzymes to mineralize the soluble insoluble tri-calcium phosphate in primary and secondary ions orthophosphates $\mathrm{H}_{2} \mathrm{PO}_{4}^{-}$and $\mathrm{HPO}_{4}^{2-}$ available to the plant [18]. 


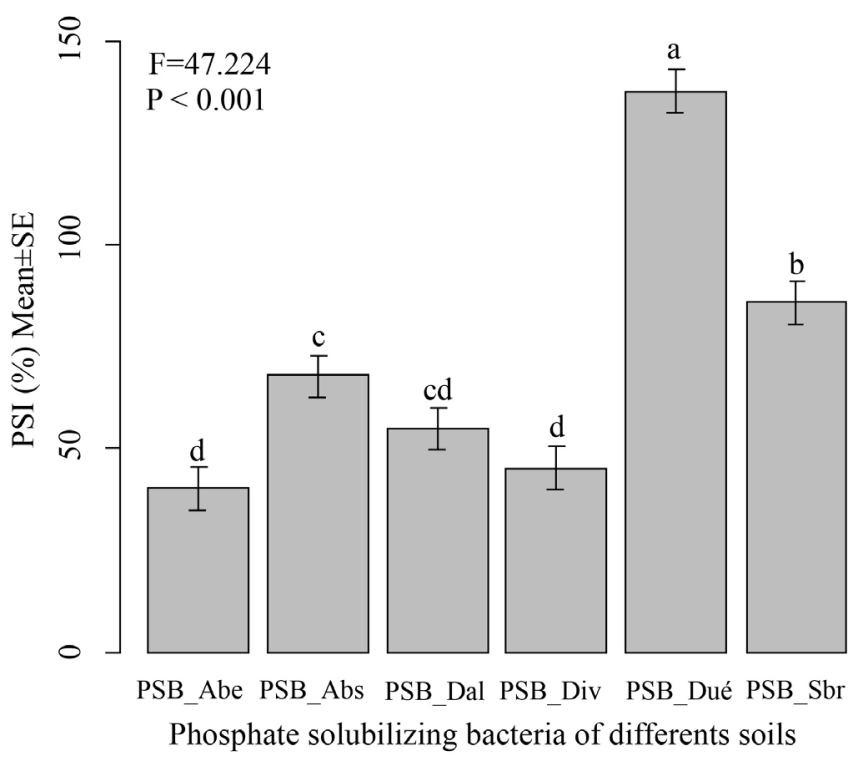

Figure 3. Bar plot of tri-calcium phosphate solubilization indices of cacao endophytic bacteria. Abe = Abengourou; Abs = Aboisso; Dal = Daloa; Div = Divo; Dué $=$ Duékoué; Sbr = Soubré; SE = Standard error. The means with the same letter are not significantly different according to Student-Newman-Keuls test at level of alpha $=0.05$.

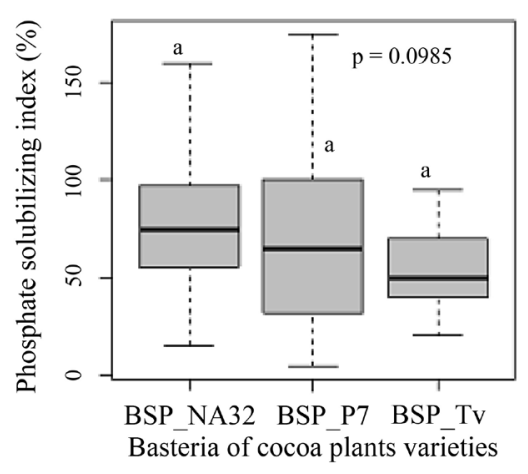

(a)

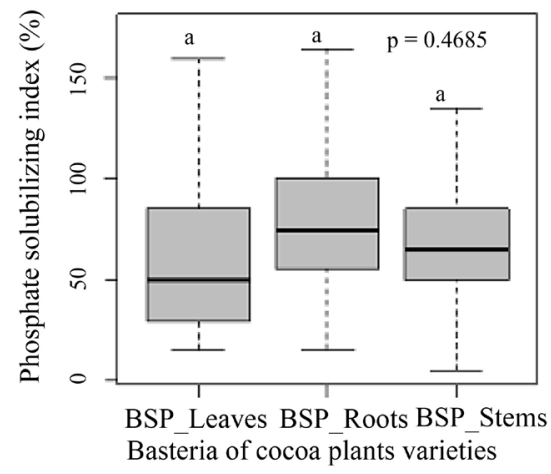

(b)

Figure 4. Box plots of tri-calcium phosphate solubilization indices of cacao endophytic bacteria. ${ }^{*}$ Medians with the same letter are not significantly different. (a) Cocoa varieties; (b) Cocoa organs.

According to many researches, the solubilization of inorganic phosphate by microorganisms occurs mainly by producing organic acids such as gluconic acid, oxalic acid, citric acid, lactic acid and aspartic acid [19]. Thus, any isolate of this study surrounded by a clear zone on the PVK medium is capable to produce organic acids to mineralize the tri-calcium phosphate. However, this selection criterion is not infallible because some bacteria do not form a transparent halo in PVK solid medium, but they can solubilize tri-calcium phosphate in a liquid broth [20]. This aspect of the result can be explained by the weak diffusion in the solid medium of the acids produced by these bacteria during their growth [21].

In addition, the solubilization index of tri-calcium phosphates of cocoa endophytic bacteria vary from one soil to another. Bacteria isolated from plants 
grown on soils sampled in the localities of Duékoué and Soubré have the highest average index. Unlike bacteria isolated from soils collected in four regions of (Daloa, Aboisso, Abengourou and Divo).

These results are similar to those obtained by Amadou [21], who isolated natural phosphate solubilizing bacteria from three soils in Mali. In this case, Solubilization index for phosphate rock varied from one soil to another. This difference can be explained by the fact that the microorganisms present in a soil low in soluble phosphate will provide more energy to mineralize insoluble phosphate reserves. Therefore, these microorganisms will be equipped with an enzymatic system more efficient than other microorganisms present in a soil rich in soluble phosphorus. The study of Balliah et al. [19] revealed that the population level of PSB was varied in different rhizospheres soils. This is mainly due to the abiotic factors of the soils. This was supported by Kucey [22], who demonstrated that PSB have been found in almost all soils tested, although the number varies with soil, climatic and cropping history. This large variation in the distribution of PSB in different soils may be due to the differences in organic carbon content of the soil [23]. It has been also reported that the percentage of phosphobacteria or Rhizobacteria may be accepted by soil physical properties, organic matter content, types and fertility and the way of farming [24]. Moreover, a study by Kassin et al. [13] who made the soil diagnosis in Côte d'Ivoire, showed that Duékoué soils are poorer in soluble form of phosphorus than the soils of Soubré, Divo, Aboisso and Abengourou localities which are more or less rich in phosphorus.

No difference was found between the solubilization indices of bacterial isolates from different varieties and organs of cocoa plants. This is explained by the fact that phosphorus is assimilated in soluble form and entered in the biological processes once inside the plant. There is no data about the endophytic bacteria of cocoa solubilizing phosphate. However, endophytic bacteria isolated from the roots and stems of the carob tree (Ceratonia siliqua L.) in Morocco showed a similar activity of solubilization of tri-calcium phosphate [25]. Various species of rhizospheres' bacteria, mycorrhizal fungi, actinomycetes and algae such as cyanobacteria have also been reported to show similar activity [26]. Moreover, in Côte d'Ivoire, preliminary studies conducted by Konate et al. [27] showed that endophytic bacteria isolated from cacao plants mainly belong to the genera of Bacillus, Pseudomonas and group of Actinomytes. These bacteria solubilizing insoluble phosphate are interesting potential agents for the biofertilization of cocoa. Thus, in the literature, these bacteria solubilizing phosphate, also called phosphate bacteria, are cited as a sustainable ecological solution in plant fertilization [11].

\section{Conclusion and Perspectives}

This study showed that cocoa trees (Theobroma cacao Linn) harbor endophytes bacteria capable of solubilizing tri-calcium phosphate. A total of 90 bacteria among $218 \%$ or $41.28 \%$ of the collection were able to solubilize the tri-calcium phosphate on solid PVK medium. Solubilization index varied between $20 \%$ and 
$200 \%$. In addition, bacteria isolated from soils collected in Duékoué region revealed the highest solubilization indices with a mean index of $137.67 \%$. The confirmation of these results in greenhouse and field conditions will allow the final selection of efficient isolates in order to develop a bacterial inoculum for the Bioremediation and Biofertilization of cocoa trees in Côte d'Ivoire.

\section{Conflicts of Interest}

The authors declare no conflicts of interest regarding the publication of this paper.

\section{References}

[1] Rfaki, A., Nassiri, L. and Ibijbijen, J. (2014) Genetic Diversity and Phosphate Solubilizing Ability of Triticum aestivum Rhizobacteria Isolated from Meknes Region, Morocco. African Journal of Microbiology Research, 8, 1931-1938. https://doi.org/10.5897/AJMR2013.5956 https://academicjournals.org/journal/AJMR/article-abstract/0AAC05444449

[2] Rfaki, A., Nassiri, L. and Ibijbijen, J. (2017) Occurrence of Phosphate Solubilizing Bacteria in the Rhizosphere of Triticum aestivum L. from Meknes, Morocco. American Journal of Microbiology and Biotechnology, 4, 1-7. https://www.academia.edu/38310050/

[3] Khan, M.S., Zaidi, A., Ahemad, M., Oves, M. and Wani, P.A. (2010) Plant Growth Promotion by Phosphate Solubilizing Fungi-Current Perspective. Archives of Agronomy and Soil Science, 56, 73-98. https://doi.org/10.1080/03650340902806469

[4] Sharma, S.B., Sayyed, R.Z., Trivedi, M.H. and Gobi, T.A. (2013) Phosphate Solubilizing Microbes: Sustainable Approach for Managing Phosphorus Deficiency in Agricultural Soils. SpringerPlus, 2, 587-601. https://doi.org/10.1186/2193-1801-2-587

[5] Khan, M.S., Zaidi, A. and Ahmad, E. (2014) Mechanism of Phosphate Solubilization and Physiological Functions of Phosphate-Solubilizing Microorganisms. In: Khan, M., Zaidi, A. and Musarrat, J., Eds., Phosphate Solubilizing Microorganisms, Springer, Cham, 31-62. https://doi.org/10.1007/978-3-319-08216-5_2 https://www.researchgate.net/publication/320322938

[6] Gurikar, C., Naik, M.K. and Sreenivasa, M.Y. (2016) Azotobacter: PGPR Activities with Special Reference to Effect of Pesticides and Biodegradation. In: Microbial Inoculants in Sustainable Agricultural Productivity, Springer India, New Delhi, 229-244. https://doi.org/10.1007/978-81-322-2647-5_13 https://link.springer.com/book/10.1007/978-81-322-2647-5

[7] Khan, M.S., Zaidi, A. and Wani, P.A. (2007) Role of Phosphate-Solubilizing Microorganisms in Sustainable Agriculture-A Review. Agronomy for Sustainable Development, 27, 29-43. https://doi.org/10.1051/agro:2006011 https://www.researchgate.net/publication/41713464

[8] Aipova, R., Aitkeldiyeva, S.A., Kurmanbayev, A.A., Sadanov, A.K. and Topalova, O.B. (2010) Assessment of Biotechnological Potential of Phosphate Solubilizing Bacteria Isolated from Soils of Southern Kazakhstan. Natural Science, 2, 841-845. https://doi.org/10.4236/ns.2010.28105

[9] Krishnananda, P.I. and Dipika, A.P. (2017) Phosphate Solubilizing Microbes: An Overview. International Journal of Current Microbiology and Applied Science, 6, 844-852. https://doi.org/10.20546/ijcmas.2017.601.099 
[10] Puri, R.R., Dangi, S.R., Dhungana, S.A. and Itoh, K. (2018) Diversity and Plant Growth Promoting Ability of Culturable Endophytic Bacteria in Nepalese Sweet Potato. Advances in Microbiology, 8, 734-761. https://doi.org/10.4236/aim.2018.89049

[11] Karpagam, T. and Nagalakshmi, P.K. (2014) Isolation and Characterization of Phosphate Solubilizing Microbes from Agricultural Soil. International Journal of Current Microbiology and Applied Science, 3, 601-614.

[12] Liu, M., Liu, X., Cheng, B.S., Ma, X.L., Lyu, X.T., Zhao, X.F., Ju, Y.L., Min, Z. and Fang, Y.L. (2016) Selection and Evaluation of Phosphate-Solubilizing Bacteria from Grapevine Rhizospheres for Use as Biofertilizers. Spanish Journal of Agricultural Research, 14, 1-10. https://doi.org/10.5424/sjar/2016144-9714

[13] Kassin, E., Snoeck, D., Nguessan, J.-C., Yao-Kouamé, A. and Camara, M. (2014) Soil Mapping Project Final Report. CNRA, Cirad, Idh, World Cocoa Foundation, Conseil du café-cacao, Côte d'Ivoire,18 p. https://www.idhsustainabletrade.com/uploaded/2017/04/CNRA-SOIL-MAPPINGPROJECT-FINAL-REPORT.pdf

[14] Ruf, F., Kla, A.G., Dja, K. and Kiendré, J. (2014) La "fiente de poulet" dans les cacaoyères de Côte d'Ivoire une révolution agroécologique et sociale. Une innovation villageoise "frugale" Rapport de mission $15 \mathrm{p}$. https://agritrop.cirad.fr/575862/1/document_575862.pdf

[15] Pikovskaya, R.I. (1948) Mobilization of Phosphorus in Soil in Connection with Vital Activity of Some Microbial Species. Microbiology, 17, 362-370.

[16] Angraini, E., Rachmania, N.M. and Widyastuti, R. (2016) Study of Potassium Solubilizing Bacteria from Limestone Mining Area in Palimanan, Cirebon Quarry. Malaysian Journal of Microbiology, 12, 62-68.

[17] R Core Team (2018) R: A Language and Environment for Statistical Computing. R Foundation for Statistical Computing, Vienna, Austria. https://www.R-project.org/

[18] Pierzynski, G.M., McDowel, R.W. and Sims, J.T. (2005) Chemistry, cycling and potential Mouvement of Inorganic Phosphorus in Soils. In: Phosphorus: Agriculture and the Environment, ASA, CSSA \& SSSA, San Antonio, TX, 53-86.

[19] Baliah, N., Tenzing, G., Pandiarajan Kumar, B. and Makesh (2016) Isolation, Identification and Characterization of Phosphate Solubilizing Bacteria from Different Crop Soils of Srivilliputtur Taluk, Virudhunagar District, Tamil Nadu. Tropical Ecology, 57, 465-474. https://www.researchgate.net/publication/298713924

[20] Nautiyal, C.S. (1999) An Efficient Microbiological Growth Medium for Screening Phosphorus Solubilizing Microorganisms. FEMS Microbiology Letters, 170, 265-270. https://doi.org/10.1111/j.1574-6968.1999.tb13383.x

[21] Amadou, H.B. (2003) Mise au point d'un inoculant biologique pour le blé irrigué du Mali. Sols et génie agroalimentaire. Faculté des Sciences de l'agriculture et de l'Alimentation, Université Laval Québec, Canada, 150 p. https://corpus.ulaval.ca/jspui/bitstream/20.500.11794/17852/1/21179.pdf

[22] Kucey, R.M.N. (1983) Phosphate-Solubilizing Bacteria and Fungi in Various Cultivated and Virgin Alberta Soils. Canadian Journal of Soil Science, 63, 671-678. https://doi.org/10.4141/cjss83-068

[23] Yadav, K. and Singh, T. (1991) Phosphorus Solubilization by Microbial Isolate from Caci fluvent. Journal of Indian Society for Sciences, 39, 89-93.

[24] Liu, H., Wu, X.Q., Ren, J.H. and Ye, J.R. (2011) Isolation and Identification of Phosphobacteria in Poplar Rhizosphere from Different Regions of China. Pedos- 
phere, 21, 90-97. https://doi.org/10.1016/S1002-0160(10)60083-5

[25] Konate, I., Koulibaly, A., Coulibaly, I. and Berraho, E.B. (2014) Phosphate Solubilizing of Carob (Ceratonia siliqua L.) Associative Bacteria Analyzed by Molecular Technique ARDRA. International Journal of Science and Research, 3, 473-479. https://www.ijsr.net/archive/v3i12/U1VCMTQzNTA=.pdf

[26] Mandlaa, Zhang, Y., Wan, Y., Tie, Y., Zhang, B., Wang, R. and Wang, G. (2019) Isolation and Characterization of Endophytic Fungi from Purslane and the Effects of Isolates on the Growth of the Host. Advances in Microbiology, 9, 438-453.

https://doi.org/10.4236/aim.2019.95026 http://www.scirp.org/pdf/AiM_2019051514330984.pdf

[27] Konate, I., Ouattara, A., Coulibaly, B., Guei, N.K.R., Amani, K., Kouakou, I.K., Filali-Maltouf, A. and Koffi, M. (2015) Phenotypic Diversity of Associative Bacteria Isolated from Roots and Stems of Cacao (Theobroma cacao) Tree in Daloa, Côte d'Ivoire. International Journal of Current Microbiology and Applied Sciences, 4, 560-570. https://www.ijcmas.com/vol-4-9/Ibrahim\%20Konate,\%20et\%20al.pdf 